\title{
Learning Style of Humanities, Commerce and Science Students: A Study on Higher Secondary Students from West Bengal
}

\author{
Sukrita Mukherjee ${ }^{1 *}$, Dr. Ishita Chatterjee ${ }^{2}$
}

\section{ABSTRACT}

Learning style is the manner in which a learner perceives, interacts with, and responds to the learning environment. Components of learning style are the cognitive, affective and physiological elements, all of which may be strongly influenced by a person's cultural background. The present study aims to understand the learning style adapted by higher secondary students. The study sample consists of 90 higher secondary school students (30 each from science, humanities and commerce background). The male female ratio was 50:50. The age range was from 16-18 years. They were all from middle socio-economic status. They were administered learning style questionnaire given by Honey and Mumford (1986). In the present study, the result indicated that in the category of Stream the F score is significant in case of Pragmatist and Reflector. In the category of Gender the F score is significant in the dimension of Pragmatist. In the category of Gender*Stream the interaction between gender and stream were not found to be significant in any of the variable, viz., Theorist, Pragmatist, Activist, and Reflector. In case of Gender, the Mean scores of male in the category of Pragmatist are highest for the Humanities group followed by Commerce group and finally by Science group. Again the mean scores of female in the category of Pragmatist are highest for the Science group followed by Humanities group and finally by Commerce group.

The present study is helpful in the field of designing educational guidance and curriculum for the Higher Secondary Students.

Keywords: Learning style, Theorist, Pragmatist, Activist, Reflector.

'Learning Style' has been defined by various scholars mostly as a signal for individual differences. These differences may manifest itself in 'life styles' and even in personality types (Zhang \& Sternberg 2005). Kolb (1984) and Honey and Mumford (1992) describe learning style

\footnotetext{
${ }^{1}$ M.A In Applied Psychology, Dept. Of Applied Psychology, University Of Calcutta, India

${ }^{2}$ Assistant Professor, Dept. Of Applied Psychology, University Of Calcutta, India

*Responding Author

(C) 2016 I S Mukherjee, I Chatterjee; licensee IJIP. This is an Open Access Research distributed under the terms of the Creative Commons Attribution License (http://creativecommons.org/licenses/by/2.0), which permits unrestricted use, distribution, and reproduction in any Medium, provided the original work is properly cited.
} 


\section{Learning Style of Humanities, Commerce and Science Students: A Study on Higher Secondary Students from West Bengal}

as an individual preferred or habitual ways of processing and transforming knowledge. It is basically the manner in which a learner perceives, interacts with, and responds to the learning environment. Components of learning style are the cognitive, affective and physiological elements, all of which may be strongly influenced by a person's cultural background. The channels- such as vision, hearing, movement, touching, or any combination of these-through which a person best understands and retains learning. Learning style refers to students' preferences for some kinds of learning Activities over others. Since learners differ in their preferences to certain learning styles, it will be important for teachers to examine the variations in their students on the features of their learning styles, because the information about learner's preference can help teachers become more sensitive to the differences students bring to the classroom (Felder \& Spurlin 2005).

Most people prefer an identifiable method of interacting with, taking in, and processing stimuli or information. Based on this concept, the idea of individualized "learning styles" originated in the 1970s, and acquired enormous popularity (Pashler, McDaniel, Rohrer, and Bjork 2008).Today the traditional belief, that learning differences are arising out of intelligence differences and different cognitive abilities has been changed and it is verified that learning differences arises out of intelligence differences and other factors such as personality characteristics, task difficulty, and learning styles (Emamepur \& Shams, 2007; Yilmaz \& Orhan, 2010).Peirce (2000) believes that learning style is the method that people prefer it over those other methods in learning such as learning in school. It is necessary that teachers, school managers and other members of instructional team take to account differences of learning styles of students. Research results revealed that paying attention to individual differences and learning characteristics of learners by teachers and others of instructional team had an important role in improving quality of learning and increase academic achievement of students (Safe, 2008; Tella \& Adeniyi, 2009).

According to Honey and Mumford (1986) there are 4 distinct learning styles. The four types of learning styles are; Theorist, Pragmatist, Activist, Reflector.

1.1 Theorist: Theorists adapt and integrate observations into complex but logically sound theories. They think problems through in a vertical, step-by-step logical way. They assimilate disparate facts into coherent theories. They tend to be perfectionists who won't rest easy until things are tidy and fit into a rational scheme. They like to analyse and synthesize. They are keen on basic assumptions, principles, theories models and systems thinking. Their philosophy prizes rationality and logic. They tend to be detached, analytical and dedicated to rational objectivity rather than anything subjective or ambiguous. Their approach to problems is consistently logical. This is their 'mental set' and they rigidly reject anything that doesn't fit with it. They prefer to maximize certainty and feel uncomfortable with subjective judgments, lateral thinking and anything flippant. 
Characteristics of a theorist: A Theorist will most value theory-based courses with wellqualified and experienced trainers, well-written books and articles.

1.2. Pragmatist: Pragmatists are keen on trying out ideas, theories and techniques to see if they work in practice. They positively search out new ideas and take the first opportunity to experiment with applications. They are the sort of people who return from courses brimming with new ideas that they want to try out in practice. They like to get on with things and act quickly and confidently on ideas that attract them. They tend to be impatient with ruminating and open-ended discussions.They are essentially practical, down to earth people who like making practical decisions and solving problems. They respond to problems and opportunities 'as a challenge'. Their philosophy is "There is always a better way" and "If it works its good".

Characteristics of a Pragmatist: A Pragmatist will find that succinct, practical books and that open and flexible learning are good ways of quickly putting new learning to practical use. Also will be particularly attracted to working on real-life projects and appreciate the help of someone who will give some valuable feedback and coaching.

1.3 Activist: Activists involve themselves fully and without bias in new experiences. They enjoy the here and now, and are happy to be dominated by immediate experiences. They are openminded, not sceptical, and this tends to make them enthusiastic about anything new. Their philosophy is: "I'll try anything once". They tend to act first and consider the consequences afterwards. Their days are filled with activity. They tackle problems by brainstorming. As soon as the excitement from one activity has died down they are busy looking for the next. They tend to thrive on the challenge of new experiences but are bored with implementation and longer term consolidation. Characteristics of an Activist: An Activist will probably want to get involved in a project or specific assignment to develop the skills on the job. Tackling activity-based training courses.

1.4 Reflector: Reflectors like to stand back to ponder experiences and observe them from many different perspectives. They collect data, both first hand and from others, and prefer to think about it thoroughly before coming to a conclusion. The thorough collection and analysis of data about experiences and events is what counts so they tend to postpone reaching definitive conclusions for as long as possible. Their philosophy is to be cautious. They are thoughtful people who like to consider all possible angles and implications before making a move. They prefer to take a back seat in meetings and discussions. They enjoy observing other people in action. They listen to others and get the drift of the discussion before making their own points. They tend to adopt a low profile and have a slightly distant, tolerant unruffled air about them. When they act it is part of a wide picture which includes the past as well as the present and others' observations as well as their own. 
Characteristics of a Reflector: A reflector will appreciate working closely with someone experienced in his area of work, and learning through observation and discussing reflections and plans with a mentor. A Reflector also learns much from books, articles and case studies.

In the present study the students of class 11 and 12 were chosen on whom the learning styles was determined. It is so because, this stage is considered as the transition period of life where the students are required to make their important decisions regarding their future career. By determining this style the effectiveness can be determined. If required any pupil can also be guided for his/her future growth and development.

\section{Need for the study:}

The present study was actually conducted to find out that whether there is a difference between males and females in terms of learning style and whether learning style differs along with the stream of study.

\section{Hypothesis:}

H1- Humanities, Science and Commerce higher secondary students will not differ among themselves with respect to their learning style - Theorist, Pragmatist, Activist, Reflector.

H2- The male higher secondary students will not differ from their female counterparts irrespective of their stream of study with respect to their learning style - Theorist, Pragmatist, Activist, Reflector.

H3-There will be no significant effect of interaction between gender and stream of study with respect to learning style of higher secondary students.

\section{METHOD:}

\section{Sample:}

For the present investigation a sample group of 90 students (30 each from Humanities, Commerce, and Science) were selected according to the requirement of the study and convenience of data collection by the researcher.

\section{Inclusion Criteria Of The Sample Group:-}

AGE: 16-18 years.

GENDER: Both male and female were taken for this study.

EDUCATIONAL QUALIFICATION: Higher secondary students.

ANY PAST HISTORY OF ILLNESS (INCLUDING BOTH PHYSICAL OR PSYCHOLOGICAL): Data of the Students having any sort of physical or psychological illness were not taken under consideration.

SOCIO-ECONOMIC STATUS: middle class and above.

AREA: Howrah, Hooghly and Kolkata. 


\section{Tools Used:}

In conducting the present study 2 questionnaire were administered. They are:

* Background information schedule

* Learning style questionnaire.

\section{Description Of The Tools:}

1. Background information schedule was developed to cover the aspects like age, gender, education, family income, number of siblings, residential locality, and overall socio economic status.

2. The Learning style questionnaire was developed by Honey and Mumford (1986). The objective of this questionnaire was made to figure out a student's liked learning style. Over the years a student have possibly created learning practices which has helped him/her in past and will help in the future too for reward more from some encounters compared to others. Given that the students are probably uninformed of this; this questionnaire will help to identify a student's learning preferences, to ensure that they are in a stronger placement to decide on learning encounters.

\section{Scoring:}

There were 40 questions. 1 point was credited for each "tick" and no point was credited for "cross". The table given below contains the following number of questions that fall under the following 4 category- viz., Theorist, Pragmatist, Activist, and Reflector respectively.

\begin{tabular}{|l|l|l|l|}
\hline THEORIST & PRAGMATIST & ACTIVIST & REFLECTOR \\
\hline & & & \\
\hline 1 & 4 & 2 & 11 \\
\hline 3 & 7 & 5 & 12 \\
\hline 6 & 9 & 8 & 16 \\
\hline 10 & 14 & 15 & 18 \\
\hline 13 & 20 & 19 & 21 \\
\hline 17 & 24 & 23 & 25 \\
\hline 22 & 27 & 26 & 29 \\
\hline 28 & 31 & 35 & 30 \\
\hline 38 & 34 & 36 & 32 \\
\hline 39 & 37 & 40 & 33 \\
\hline TOTAL $=$ & TOTAL $=$ & TOTAL $=$ & TOTAL $=$ \\
\hline
\end{tabular}

The Chronbach's Alpha method of Reliability was used in order to determine the extent to which each of the domains is reliable. After administering it was found out as following:

* The Chronbach's Alpha for the category of Theorist was found out to be 0.638. The numbers of items present under this domain were 10.

(C) The International Journal of Indian Psychology, ISSN 2348-5396 (e)| ISSN: 2349-3429 (p) | 18 
* The Chronbach's Alpha for the category of Pragmatic was found out to be 0.579. The numbers of items present under this domain were 10.

* The Chronbach's Alpha for the category of Activist was found out to be 0.763 . The numbers of items present under this domain were 10.

* The Chronbach's Alpha for the category of Reflector was found out to be 0.690 . The numbers of items present under this domain were 10.

\section{RESULTS AND DISCUSSION:}

\section{Brief Summary Of The Mean And S.D Of The Variables Under Study (Learning Style).}

\begin{tabular}{|l|l|l|l|l|l|l|}
\hline VARIABLES & HUMANITIES & \multicolumn{2}{l|}{ COMMERCE } & \multicolumn{2}{l|}{ SCIENCE } \\
\hline & MEAN & S.D & MEAN & S.D & MEAN & S.D \\
\hline THEORIST & 8.03 & 1.99 & 7.33 & 1.74 & 7.00 & 1.68 \\
\hline PRAGMATIC & 6.10 & 2.37 & 7.63 & 1.30 & 7.40 & 1.52 \\
\hline ACTIVIST & 5.97 & 2.37 & 5.70 & 2.04 & 5.83 & 1.80 \\
\hline REFLECTOR & 6.50 & 2.36 & 7.80 & 1.88 & 7.83 & 1.84 \\
\hline
\end{tabular}

Hypothesis 1 and 2 are accepted for the dimensions of Pragmatist. For rest of the dimensions, the hypothesis is not accepted. Hypothesis 3 has also been accepted for the dimension of Reflector as the interaction effect between stream and gender over there has been found to be significant.

Statistical Analysis (Anova).

\begin{tabular}{|l|l|l|l|l|l|l|}
\hline DIMENSION & & $\begin{array}{l}\text { TYPE III } \\
\text { SUM OF } \\
\text { SQUARES }\end{array}$ & $\begin{array}{l}\text { MEAN } \\
\text { SQUARES }\end{array}$ & F & SIGNIFICANCE \\
\hline & Stream & 16.689 & 2 & 8.344 & 2.581 & .082 \\
\hline THEORIST & Gender & 9.344 & 1 & 9.344 & 2.890 & .093 \\
\hline & stream * gender & 4.689 & 2 & 2.344 & .725 & .487 \\
\hline & & & & & & \\
\hline & Stream & 40.956 & 2 & 20.478 & 7.905 & $.001^{*}$ \\
\hline PRAGMATIST & Gender & 45.511 & 1 & 45.511 & 17.569 & $.000^{*}$ \\
\hline & stream * gender & 15.756 & 2 & 7.878 & 3.041 & .053 \\
\hline & & & & & & \\
\hline ACTIVIST & Stream & 1.067 & 2 & .533 & .120 & .887 \\
\hline & Gender & .011 & 1 & .011 & .002 & .960 \\
\hline & stream * gender & 3.822 & 2 & 1.911 & .430 & .652 \\
\hline & & & & & & \\
\hline & Stream & 34.689 & 2 & 17.344 & 4.290 & $.017^{*}$ \\
\hline & Gender & 11.378 & 1 & 11.378 & 2.814 & .097 \\
\hline & Stream * gender & 5.489 & 2 & 2.744 & .679 & .510 \\
\hline
\end{tabular}


Learning Style of Humanities, Commerce and Science Students: A Study on Higher Secondary Students from West Bengal

Brief Summary Of The Mean Scores Of The Variables Under Study In Terms Of Stream And Gender Of The Three Different Groups (Humanities, Commerce And Science) Is Presented Below.

\begin{tabular}{|l|l|l|l|l|l|l|}
\hline VARIABLES & \multicolumn{2}{l}{ HUMANITIES } & \multicolumn{2}{l|}{ COMMERCE } & \multicolumn{2}{l|}{ SCIENCE } \\
\hline & MALE & FEMALE & MALE & FEMALE & MALE & FEMALE \\
\hline & MEAN & MEAN & MEAN & MEAN & MEAN & MEAN \\
\hline THEORIST & 7.40 & 4.80 & 7.80 & 6.87 & 7.00 & 7.00 \\
\hline PRAGMATIST & 8.53 & 7.53 & 8.00 & 7.27 & 7.87 & 7.80 \\
\hline ACTIVIST & 5.87 & 6.07 & 5.53 & 5.87 & 6.13 & 5.53 \\
\hline REFLECTOR & 7.13 & 5.87 & 8.20 & 7.40 & 7.86 & 6.93 \\
\hline
\end{tabular}

From the Anova table, it has been found that in the category of Stream the $\mathrm{F}$ score [7.905(0.001)] is significant in case of Pragmatist. Again for the dimension of Reflector F score [4.290(0.017)] has been found to be significant indicating that the Humanities, Science and Commerce students significantly differ among themselves. For the dimensions of Theorist and Activist the F score have not been found to be significant. In general the Commerce stream students have scored highest, followed by the Science stream students and the least score made by the Humanities group.

It has also been found that in the category of Gender the F score is significant [17.569(0.000)] in the dimension of Pragmatist. For other dimensions, namely, Theorist, Activist and Reflector the F score have not been found to be significant. The Mean scores of males under the category of Pragmatist are highest for the Humanities group followed by Commerce group and finally by Science group. Again the mean scores of females under the category of Pragmatist are highest for the Science group followed by Humanities group and finally by Commerce group.

In the category of Gender*Stream category, the scores of the interaction between gender and stream has not been found to be significant in any of the dimensions of learning style.

A study was conducted by Malathi and Malini (2006) on the relationship between learning style and achievement among higher secondary students of Chennai. The study revealed that there is high correlation between learning style and achievement, which implies that higher the achievement better was the learning style among higher secondary students. In this study no such gender and interaction between gender and stream (Gender*Stream) were not found to be significant. Bada and Okan (2000) found that for students to achieve effective learning, teachers must give special consideration to the skills and assumptions of learners and to their individual learning preferences. Research by Hardigan and Sisco (2001) also supports the idea that students' preferred learning styles differ. Ross, Drysdale and Schulz (2001) in a study found that learning styles influence the types of learning experiences that students find effective, comfortable and growth promoting. It is therefore essential that teachers should develop

(c) The International Journal of Indian Psychology, ISSN 2348-5396 (e)| ISSN: 2349-3429 (p) | 20 
appropriate learning experience to cater to the learning style of the students and thus empower them. Liaw and Huang (2000) are of the view that instructional interactivity occurs when students engage in discussion or activities with their instructor on topics related to content. In this study, the scores of the interaction between gender and stream has been found to be significant only in case of Reflector dimensions of learning style. The articles of Felder et al. (2004) and Haller et al. (2000) discuss on the effectiveness of co-operative learning groups. The articles support the idea that through proper teacher facilitation and formation of co-operative groups, students were able to learn effectively and with higher level of understanding. Agrawal and Chawla (2005) conducted a study on the influence of co-operative learning on academic achievement among 5th graders. It was found that co-operative learning environment provided students with opportunities to analyse, synthesise and evaluate ideas co-operatively. Golden (2001) investigated the relationship of learning styles with personality type. The results of the study revealed that two personality Profiler Facet Scales-Talkative and Reflective significantly influenced scores on Reflective Observation Scale of Kolb's Learning Style Inventory. However, no significant relationships were found to exist between the Facet Scale and Active Experimentation Mode.

\section{IMPLICATIONS}

1. This study is also helpful in determining about the learning styles of higher secondary students from different streams; clarifying the effects of teaching methods that are incongruent with a student's style; and identifying the connections and interaction between style, developmental stage, disciplinary perspectives, and epistemology.

2. The present study helps to give a better view of the learning style adapted by the students which reveals the personality traits of the students and it will help in the determination of their professional placement in future.

3. Learning style based on pedagogical practices can be undertaken in classroom situations.

\section{REFERENCES}

Agrawal, R., and Chawla, N., (2005). Influence of cooperative learning on academic achievement. Journal of Indian Education, XXXI (2). Pg:52-59.

Bada, E., \& Okan, Z., (2000). Students' language learning preferences. TESL-EJ, 4.(3), A-1, 115.

Emamepur, S. Shams, H. (2007).Learning and cognitive styles. Tehran, Samt press.

Felder, R.M. \& Spurlin, J. E. (2005).Application, reliability, and validity of the index of learning styles. Intl. J. Engr. Education, 21(1), 103-112.

Felder, R.M., \& J. Spurlin (2004). "Reliability and Validity of the index of Learning styles: a Meta-analysis. International Journal Of Engineering Education, 21(1). Pg:103-112. 
Golden, J.P. (2001) A Canonical Analysis of Extroverting/Introverting Personality Traits and Reflective Observation/ Active Experimentation Learning Modes: Dissertation Abstracts International, Vol. 62(12), 4055-A.

Haller, C.R., Gallaghar, V., Weldon, T.R., \& Felder, R.M., (2000).Dynamics of peer education in cooperative learning workshops. Journal of Engineering Education, 89(3).Pg: 285293.

Hardigan, P.C., \&Sisco, B.R., (2001). An analysis of learning styles among full time undergraduate college students. (Report No.HE-033-941). Washington DC: ERIC Clearinghouse on Higher Education. (ERIC Document Reproduction Service No. ED 451811).

Honey, P. \& Mumford, A. (1992). The manual of learning styles. Maidenhead: Peter Honey.

Kolb, D. A. (1984). Experiential learning: Experience as a source of learning and development, Englewood Cliffs, NJ: Prentice Hall.

Liaw, S., \& Huang, H., (2000).Enhancing interactivity in web-based instruction: A review of literature. Educational Technology, 39(3).Pg: 41-45.

Malathi, S., \& Malini, E., (2006).Learning style of higher secondary students of Tamil Nadu. EDUTRACKS, Vol. 5(10). Pg:27-29.

Pashler, H. Mcdaniel, M. Rohrer, D. Bjork, R. (2008). Learning Styles: Concepts and evidence. Psychological Science in the Public Interest, 9, 105-119.

Peirce, W. (2000). Understanding students, difficulties in reasoning, part two: The perspective from research in learning styles and cognitive styles.

Ross, J.L., Drysdale, M.T., \& Schulz, R.A., (2001). Cognitve learning styles and academic performance in two postsecondary computer application courses. Journal of Research on Computing in Education,33. Pg:400-412.

Safe, A. (2008). New educational psychology. Furth press, Tehran, Duran publication.

Tella, A., \& Adeniyi, O. (2009).Locus of control, interest in schooling, self-efficacy and academic achievement. Cypriot Journal of Educational Sciences, 4(3).

Y1lmaz, M., \& Orhan, F. (2010). High school students educational usage of Internet and their learning approaches. World Journal on Educational Technology, 2(2), 100-112.

Zhang, L.-F.\& Sternberg, R.J. (2005).A threefold model of intellectual styles. Educational Psychology Review, 17(1), 2.

How to cite this article: S Mukherjee, I Chatterjee (2016), Learning Style of Humanities, Commerce and Science Students: A Study on Higher Secondary Students from West Bengal, International Journal of Indian Psychology, Volume 3, Issue 3, No. 10, DIP: 18.01.173/20160303, ISBN: 978-1-365-19879-3 